\section{Increasing Cell Size and Reducing Medium Compression Enhance Lettuce Transplant Quality and Field Production}

\author{
Silvana Nicola ${ }^{1}$ and Daniel J. Cantliffe ${ }^{2}$ \\ Horticultural Sciences Department, University of Florida, Gainesville, \\ FL 32611
}

Additional index words. Lactuca sativa, growth rates, containerized vegetable transplants, planter flats, early maturity

\begin{abstract}
South Bay' lettuce (Lactuca sativa L.) seedlings were grown in a greenhouse during winter, spring, and fall to investigate the effect of cell size and medium compression on transplant quality and yield. Four Speedling planter flats $\left(1.9-, 10.9-, 19.3-, 39.7-\mathrm{cm}^{3}\right.$ cells) and two medium compression levels [noncompressed and compressed (1.5 times in weight)] were tested. The two larger cell sizes and compression of the medium led to increased plant shoot growth. Conversely, root weight ratio [RWR $=$ (final root dry weight $\div$ final total dry weight + initial root dry weight $\div$ initial total dry weight $) \div 2$ ] was highest with the smaller cells without medium compression. Lettuce transplants were field-grown on sand and muck soils. The larger cells delayed harvest by $>2$ weeks for plants grown on muck soil, but yield was unaffected. When grown on sandy soil, earliness was enhanced from plants grown in 19- and $40-\mathrm{cm}^{3}$ cells, but head weights were not affected in the spring

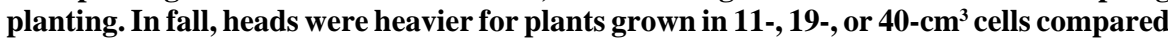
with those from $2-\mathrm{cm}^{3}$ cells. On sandy soil, harvest was delayed 13 days in spring and 16 days in fall for plants grown in the smallest cell size. Using the two smaller cell sizes saved medium and space in the greenhouse and increased the root growth ratio, but it led to reduced plant growth compared to using the bigger cells. Yield and earliness were more related to season and soil type than to transplant quality. On sandy soil, plants grown in 2- and 11- $\mathrm{cm}^{3}$ cells matured later, and yield was significantly decreased $(8.6 \%)$ in fall by using plants from the $2-\mathrm{cm}^{3}$ cells compared to the other sizes. From our results, compressing the medium in the cells was not justified because it is more costly and did not benefit yield in the field.
\end{abstract}

Greenhouse, containerized, vegetable transplant production is a standard procedure in Europe and has become more widely used in North America in the last 10 years. Cell volume and compression of the medium can modify the quality of greenhouse-grown transplants by altering plant density, competition for light and water, nutrient retention, and root volume required to fill cells (Aguila-Sancho, 1988).

Differences in plant condition at transplanting, resulting from differences in container cell size and spacing in the flat, affected stand, earliness, yield, and quality (Chipman, 1961; Knavel, 1965; Kretchman and Short, 1977; Nicklow and Minges, 1962). Generally, tomato (Lycopersicon esculentum Mill.) and pepper (Capsicum annuum L.) growth and earliness increased as root cell size increased; however, total yields were unaffected (Basoccu and Nicola, 1989, 1990; Weston and Zandra, 1986). Hall (1989) reported that greater cell volume was associated with larger watermelon

Received for publication 28 Aug. 1995. Accepted for publication 29 Nov. 1995. Florida Agricultural Expt. Station Journal Series no. R-04330. The cost of publishing this paper was defrayed in part by the payment of page charges. Under postal regulations, this paper therefore must be hereby marked advertisement solely to indicate this fact.

${ }^{1}$ Graduate Research Assistant.

${ }^{2}$ Professor.
[Citrullus lanatus (Thunb.) Matsum. and Nakai] transplant size, more rapid vine growth, and higher late and total yield. Vavrina et al. (1993) found no effect of cell volume on total watermelon yield. When head lettuce was established by containerized transplants, larger root cell volume increased earliness but did not increase head weight (Gianquinto, 1991). A larger root system improved stand establishment by decreasing transplant shock in lettuce (Gianquinto, 1991) and tomato (Weston and Zandra, 1986).

Pepper transplant growth increased with compressed medium, but earliness and total yields were not affected (Basoccu and Nicola, 1990). Basic soil and physiological research showed that pore size and distribution in the growing medium are critical factors in determining water storage and transmission while maintaining adequate $\mathrm{O}_{2}$ (Drew and Stolzy, 1991). Plant root tips growing through structureless media, without continuous large pores or cracks, elongate by exerting pressure on the obstructing soil particles, thereby displacing them (Bennie, 1991). Paths of lower mechanical impedance give rise to preferential root growth. Mechanical impedance caused changes in root morphology, externally and internally (Bennie, 1991). Steenkamp (1987), Baligar et al. (1975), and Prihar et al. (1971) found an elaborate production of sclerified cells in the cortical and vascular tissues of maize (Zea mays L.) and soybean (Glycine max L.) plants grown in compacted soil. A shorter, shallower, and less proliferated root system will exploit a smaller volume of soil for plant nutrients and water. A shorter root length per unit soil volume or a lower rooting density requires that the roots maintain a water- and nutrient-uptake rate higher than normal to satisfy the demand of the growing seedling (Bennie, 1991).

We hypothesize that compressing the growth medium can decrease pore size and $\mathrm{O}_{2}$ content and create mechanical impedance to transplant root growth. These factors may have a negative effect on nutrient and water uptake and reduce root growth. Little information is available on the effects of container cell volume and medium compression on lettuce transplant production. Our studies were conducted to investigate the effects of cell size and medium compression on lettuce transplant quality and yield from sandy and muck soils over two seasons evaluated in Florida.

\section{Materials and Methods}

Transplant growth. 'South Bay' lettuce was sown on 15 Jan. (Winter 1993), 3 Mar. (Spring 1993), and 26 Sept. 1993 (Fall 1993). Seedlings were grown in polystyrene Speedling (Sun City, Fla.) planter flats with inverted pyramid cells of four sizes (Table 1) and were raised in a greenhouse at the Univ. of Florida, Gainesville. A Speedling-fortified growing medium was used at two compression levels: noncompressed and compressed. The noncompressed medium was poured into the flats and leveled by hand. For the compressed treatment, $50 \%$ more medium (by weight) was compressed by hand into the flats. Seeded flats were covered with recycled perlite and then incubated in a growth chamber at $16 \mathrm{C}$ for $48 \mathrm{~h}$ and transferred to a glasshouse (18C minimum/30C maximum). After seedling emergence, transplants were uniformly irrigated overhead as needed. They were fertigated using a flotation system (Beirenger and Bostdorff, 1989), twice in winter [12 and 21 days after sowing (DAS)] and spring (12 and 16 DAS) and once in fall (12 DAS). In each fertigation, the fertilizer (20N-4P-16K) was given for 30 min with $\mathrm{N}$ at $50 \mathrm{mg} \cdot$ liter $^{-1}$. The plants were grown with the natural photoperiod extended to $16 \mathrm{~h}$ by $1000-\mathrm{W}$, high-pressure sodium lamps $\left(250 \mu \mathrm{mol} \cdot \mathrm{m}^{-2} \cdot \mathrm{s}^{-1}\right.$ photosynthetic photon flux). The treatments (cell size and me-

Table 1. Side length, area, depth, and volume of root cells of Speedling planter flats. ${ }^{2}$

\begin{tabular}{|c|c|c|c|c|}
\hline \multirow[b]{2}{*}{$\begin{array}{l}\text { Flat } \\
\text { model }\end{array}$} & \multicolumn{3}{|c|}{ Cell } & \multirow[b]{2}{*}{$\begin{array}{c}\text { Designation } \\
\left(\mathrm{cm}^{3}\right) \\
\end{array}$} \\
\hline & $\begin{array}{l}\text { Side length } \\
(\mathrm{cm})\end{array}$ & $\begin{array}{l}\text { Depth } \\
(\mathrm{cm})\end{array}$ & $\begin{array}{l}\text { Vol. } \\
\left(\mathrm{cm}^{3}\right)\end{array}$ & \\
\hline 882 & 1.1 & 2.9 & 1.9 & 2 \\
\hline F392A & 1.9 & 6.4 & 10.9 & 11 \\
\hline $\mathrm{F} 242 \mathrm{~A}$ & 2.5 & 6.4 & 19.3 & 19 \\
\hline F128A & 3.8 & 6.4 & 39.7 & 40 \\
\hline
\end{tabular}

${ }^{2}$ Speedling planter flats are made of expandable polystyrene and are produced in various sizes, with a descriptive flat model number indicating the cell count. The flats' outside dimensions are $67.6 \mathrm{~cm}$ long and $34.6 \mathrm{~cm}$ wide. Cells are shaped as square inverted pyramids. 
dium compression) were arranged in a factorial combination as part of a randomized complete-block design with four replications. Each replication consisted of a single tray.

In spring, additional treatments were introduced. Plants from the smallest cell size (2 $\mathrm{cm}^{3}$ ) were grown one additional week in the greenhouse to extend the duration of transplant growth with noncompressed and compressed medium.

In winter, plants were sampled twice, 18 and 24 DAS. In spring and fall, they were sampled at transplanting (22 or 29 DAS in spring, the latter for those plants grown one additional week in the greenhouse, 26 DAS in fall). The sampled plants were pulled from the tray and washed gently before taking measurements. Five individual plants were measured at each sampling, and the data were pooled.

True leaf count, leaf length (longest leaf), and leaf area (model LI-3100 leaf area meter; LI-COR, Lincoln, Neb.) were measured at transplanting. Shoot and roots were separated and oven-dried at 70C for 3 days, and dry weights were measured. Growth analysis was conducted according to Hunt $(1978,1982)$. Relative growth rate $\{$ RGR $=[\ln$ (final total dry weight) $-\ln$ (initial total dry weight)] $\div$ (final time - initial time) $\}$, net assimilation rate $\{\mathrm{NAR}=\{($ final total dry weight - initial total dry weight) $\times[\ln$ (final leaf area) $-\ln$ (initial leaf area) $]\} \div$ [(final leaf area - initial leaf area) $\times($ final time - initial time $)]\}$, leaf area ratio $[\mathrm{LAR}=$ (final leaf area $\div$ final total dry weight + initial leaf area $\div$ initial total dry weight $) \div 2$ ], specific leaf area [SLA = (final leaf area $\div$ final leaf dry weight + initial leaf area $\div$ initial leaf dry weight $\div 2$ ], leaf weight ratio $[\mathrm{LWR}=$ (final leaf dry weight $\div$ final total dry weight + initial leaf dry weight $\div$ initial total dry weight $) \div 2$ ], and root weight ratio $[\mathrm{RWR}=($ final root dry weight $\div$ final total dry weight + initial root dry weight $\div$ initial total dry weight $) \div 2$ ] were computed. The initial time was 5 DAS on a 12-plant sample, and the final time was on the day of transplanting.

Field growth in sandy soil. Transplants were planted on an Arredondo fine sandy (loamy, siliceous, hyperthermic Grossarenic Paluedults) soil at the Univ. of Florida Horticultural Unit, Gainesville, on 25 Mar. or 1 Apr. 1993 (spring ) and on 23 Oct. 1993 (fall). Beds ( $1 \mathrm{~m}$ wide and $0.3 \mathrm{~m}$ high) were spaced $1.5 \mathrm{~m}$ center to center. Preplant fertilizer $(13 \mathrm{~N}-4 \mathrm{P}$ $13 \mathrm{~K})$ was applied and rotovated into the bed according to soil analysis at $560 \mathrm{~kg} \cdot \mathrm{ha}^{-1}$. Methyl bromide : chloropicrin $(67: 33)$ was injected at $30 \mathrm{~g} \cdot \mathrm{m}^{-2}$ into the beds, which were covered with white-on-black plastic mulch $(0.038 \mathrm{~mm}$, Thermofilm-IR, PolyonBarkai, Israel). Water was applied every 1 or 2 days, according to the season and the weather conditions, using drip irrigation lines placed on the center of the bed with the emitters spaced $0.3 \mathrm{~m}$ apart. Fertilizer $\left[\mathrm{NH}_{4} \mathrm{NO}_{3}, \mathrm{H}_{3} \mathrm{PO}_{4}\right.$, and $\left.\mathrm{KNO}_{3}\left(112 \mathrm{~N}-9 \mathrm{P}-112 \mathrm{~K} \mathrm{~kg} \cdot h \mathrm{a}^{-1}\right)\right]$ was applied weekly through the drip system by Venturi fertilizer injector (Netafim Irrigation, Altamonte Springs, Fla.), with the last application 2 weeks before harvest.

Plots were elevated, double-row beds; within-row and between-row spacing was 0.3 $\mathrm{m}$. The field experiment design was a randomized complete block with four replications.

Spring. Leaf area and shoot, root, and total dry weights were measured 12 days after transplanting (DAT), and RGR, NAR, LAR, SLA, LWR, and RWR were computed using six individual plants per experimental unit. Six individual plants per replicate were measured for shoot, root, and total dry weights 26 DAT, and RGR and RWR were computed. The initial time for the growth analysis was considered the transplanting day. Harvest was on 12 or 25 May 1993, depending on the treatment, at head maturity. All plants grown in the greenhouse in 19- and $40-\mathrm{cm}^{3}$ cells were harvested 48 DAT. Similarly, all plants grown in $2-\mathrm{cm}^{3}$ cells were harvested 61 DAT. For plants grown in $11-\mathrm{cm}^{3}$ cells, two of the four replicates from noncompressed medium were harvested 48 DAT and the other two 61 DAT. Three of four replicates of plants grown in compressed medium were harvested 48 DAT and the last one 61 DAT. Weight, height, width, and stem length (following longitudinal sectioning) of 10-head samples were measured for each replication.

Fall. Harvest was on 5, 10, or 21 Jan. 1994, depending on the treatment, at head maturity. Transplants grown in all the $40-\mathrm{cm}^{3}$ cells and in most of the $19-\mathrm{cm}^{3}$ cells were harvested 74 DAT. Part of the plants grown in $11-\mathrm{cm}^{3}$ cells were harvested 79 DAT. All the plants from the $2-\mathrm{cm}^{3}$ cells and the remaining plants raised in $11-$ and $19-\mathrm{cm}^{3}$ cells were harvested 90 DAT. Weight, height, width, and stem length of 15 heads were measured for each replication.

Field growth in muck soil. Transplants were planted on a Pahokee muck (euic, hyperthermic Lithic Medisaprist) soil at South Bay Growers, Belle Glade, Fla., on 21 Oct. 1993 (fall). The beds were elevated, double rows on $0.9-\mathrm{m}$ centers, with the plants spaced $0.3 \mathrm{~m}$ apart within the row. Fertilizer application, fertilization rates, subseepage irrigation, and other cultural practices were commercial standards for local growers. The experiment design was a randomized complete block with four replications.

Harvest was on 19 Dec. 1993 or 4 Jan. 1994, depending on the treatment, at head maturity. Plants grown in 2- and $11-\mathrm{cm}^{3}$ cells were harvested 54 DAT. Plants from 19- and $40-\mathrm{cm}^{3}$ cells were harvested 73 DAT. However, four individual plots were not harvested because early bolting resulted in nonmarketable heads. Weight, height, width, and stem length of 15 heads were measured for each replicate.

Statistical analysis. Data were subjected to analysis of variance, and preplanned orthogonal comparisons were made among the cell size treatments. When a cell size $\times$ medium

Table 2. Shoot and root growth characteristics of lettuce seedlings as affected by cell size and medium compression (noncompressed $=\mathrm{NC}$ and compressed $=\mathrm{C}$ ) 24 days after seeding (winter)

\begin{tabular}{|c|c|c|c|c|c|c|c|c|c|c|c|c|}
\hline \multirow[b]{3}{*}{ Growing conditions } & \multicolumn{4}{|c|}{ Leaf } & \multicolumn{3}{|c|}{ Dry wt } & \multirow{3}{*}{$\begin{array}{c}\mathrm{RGR}^{\mathrm{y}} \\
\left(\mathrm{mg} \cdot \mathrm{mg}^{-1} \cdot \mathrm{d}^{-1}\right)\end{array}$} & \multirow{3}{*}{$\begin{array}{c}\mathrm{NAR}^{y} \\
\left(\mathrm{mg} \cdot \mathrm{cm}^{-2} \cdot \mathrm{d}^{-1}\right)\end{array}$} & \multirow{3}{*}{$\begin{array}{c}\mathrm{LAR}^{\mathrm{y}} \\
\left(\mathrm{cm}^{2} \cdot \mathrm{mg}^{-1}\right)\end{array}$} & \multirow{3}{*}{$\begin{array}{c}\text { SLA }^{y} \\
\left(\mathrm{~cm}^{2} \cdot \mathrm{mg}^{-1}\right)\end{array}$} & \multirow{3}{*}{$\begin{array}{c}\mathrm{RWR}^{\mathrm{y}} \\
\left(\mathrm{mg} \cdot \mathrm{mg}^{-1}\right)\end{array}$} \\
\hline & \multicolumn{2}{|c|}{ Count } & \multirow{2}{*}{$\begin{array}{l}\text { Length }^{\mathrm{z}} \\
(\mathrm{mm})\end{array}$} & \multirow{2}{*}{$\begin{array}{l}\text { Area } \\
\left(\mathrm{mm}^{2}\right)\end{array}$} & \multirow{2}{*}{$\begin{array}{l}\text { Shoot } \\
(\mathrm{mg})\end{array}$} & \multirow{2}{*}{$\begin{array}{l}\text { Root } \\
(\mathrm{mg})\end{array}$} & \multirow{2}{*}{$\begin{array}{l}\text { Total } \\
(\mathrm{mg})\end{array}$} & & & & & \\
\hline & $\mathrm{NC}$ & $\mathrm{C}$ & & & & & & & & & & \\
\hline \multicolumn{13}{|l|}{ Flat designation $\left(\mathrm{cm}^{3}\right)$} \\
\hline 2 & 2.3 & 2.9 & 78 & 1267 & 22 & 5 & 27 & 0.179 & 0.737 & 0.244 & 0.298 & 0.182 \\
\hline 11 & 3.9 & 3.9 & 108 & 3031 & 46 & 9 & 55 & 0.216 & 0.717 & 0.286 & 0.341 & 0.171 \\
\hline 19 & 4.2 & 4.3 & 121 & 4366 & 70 & 11 & 81 & 0.237 & 0.767 & 0.279 & 0.323 & 0.158 \\
\hline 40 & 4.6 & 4.5 & 102 & 4285 & 75 & 15 & 90 & 0.242 & 0.864 & 0.250 & 0.299 & 0.172 \\
\hline Significance & \multicolumn{2}{|c|}{$<0.001^{\mathrm{x}}$} & $<0.001$ & $<0.001$ & $<0.001$ & $<0.001$ & $<0.001$ & $<0.001$ & 0.002 & 0.003 & 0.008 & $<0.001$ \\
\hline \multicolumn{13}{|l|}{ Orthogonal contrasts } \\
\hline $2 \mathrm{~cm}^{3}$ vs. others ${ }^{\mathrm{w}}$ & \multicolumn{2}{|l|}{$<0.001$} & $<0.001$ & $<0.001$ & $<0.001$ & $<0.001$ & $<0.001$ & $<0.001$ & 0.126 & 0.009 & 0.043 & $<0.001$ \\
\hline $\begin{array}{l}11 \text { vs. } 19 \text { and } \\
40 \mathrm{~cm}^{3}\end{array}$ & \multicolumn{2}{|l|}{$<0.001$} & 0.248 & $<0.001$ & $<0.001$ & $<0.001$ & $<0.001$ & $<0.001$ & 0.004 & 0.045 & 0.013 & 0.106 \\
\hline 19 vs. $40 \mathrm{~cm}^{3}$ & & & $<0.001$ & 0.776 & 0.305 & 0.003 & 0.133 & 0.337 & 0.012 & 0.021 & 0.072 & 0.003 \\
\hline $\mathrm{NC}$ vs. $\mathrm{C}\left(11 \mathrm{~cm}^{3}\right)$ & \multicolumn{2}{|l|}{$>0.999$} & & & & & & & & & & \\
\hline \multicolumn{13}{|l|}{ Media compression } \\
\hline $\mathrm{NC}$ & 3.7 & & 95 & 2979 & 53 & 12 & 64 & 0.218 & 0.832 & 0.241 & 0.295 & 0.181 \\
\hline $\mathrm{C}$ & 3.9 & & 110 & 3496 & 54 & 9 & 63 & 0.219 & 0.710 & 0.289 & 0.336 & 0.161 \\
\hline Significance & 0.184 & & $<0.001$ & 0.017 & 0.699 & 0.002 & 0.700 & 0.918 & $<0.001$ & $<0.001$ & 0.001 & $<0.001$ \\
\hline Interaction & \multicolumn{2}{|c|}{0.035} & 0.498 & 0.980 & 0.824 & 0.091 & 0.625 & 0.245 & 0.307 & 0.417 & 0.493 & 0.716 \\
\hline
\end{tabular}

${ }^{2}$ Measure taken on the longest leaf.

${ }^{y} \mathrm{RGR}=$ relative growth rate, $\mathrm{NAR}=$ net assimilation rate, $\mathrm{LAR}=$ leaf area ratio, $\mathrm{SLA}=$ specific leaf area, and $\mathrm{RWR}=$ root weight ratio.

${ }^{x} P$ value for the main effect.

${ }^{\mathrm{w}}$ Others $=11+19+40 \mathrm{~cm}^{3}$ pooled treatments. 
compression interaction was significant, these comparisons were based on noncompressed medium treatments. Effect of medium compression also was evaluated for plants grown in $11-\mathrm{cm}^{3}$ cells.

\section{Results and Discussion}

Transplant growth (winter). Trends 18DAS were similar to those 24 DAS, hence only the latter data are shown (Table 2). Plants grown in $2-\mathrm{cm}^{3}$ cells had shorter leaves; less leaf area; lower dry weights; lower RGR, LAR, and SLA values; and higher RWR compared with plants grown in all other flats. Reduced plant growth was not due to low-light levels from overcrowding of the plants because the plants were not etiolated; it was more likely caused by the reduced water-holding and fertilizer capacity of the small medium volume (data not shown).

Plants grown in the standard tray used by Speedling for lettuce transplant production $\left(11-\mathrm{cm}^{3}\right.$ cells) had less leaf area and lower shoot, root, and total dry weights and RGR, NAR, LAR, and SLA values compared to 19and $40-\mathrm{cm}^{3}$ cells. Plants from the largest cells $\left(40 \mathrm{~cm}^{3}\right)$ had shorter leaves than those from the $19-\mathrm{cm}^{3}$ cells; however, leaf area, shoot and total dry weights, RGR, and SLA were not affected. These data suggest that optimal growth of lettuce seedlings occurred in a 19$\mathrm{cm}^{3}$ cell volume. The NAR of plants from 40$\mathrm{cm}^{3}$ cells was higher $\left(0.864 \mathrm{mg} \cdot \mathrm{cm}^{-2} \cdot \mathrm{d}^{-1}\right)$ than that from the $19-\mathrm{cm}^{3}$ cells $\left(0.767 \mathrm{mg} \cdot \mathrm{cm}^{-2} \cdot \mathrm{d}^{-1}\right)$, indicating a greater dry-matter accumulation per leaf area, but not enough to induce a higher RGR in these plants (since RGR $=$ NAR $\times$ LAR, and LAR decreased).

Medium compression increased leaf length and area (Table 2). Leaf area increased more than the leaf weight (as indicated by SLA values). Plants grown in noncompressed me- dium had higher NAR and RWR values, but not RGR values, compared to plants grown in compressed medium. Root dry weight was less in plants grown in compressed than in noncompressed medium.

A cell size $\times$ medium compression interaction led to fewer leaves in plants grown in 2$\mathrm{cm}^{3}$ cells and noncompressed medium than in those from the other cell sizes. Leaf count was reduced in plants grown in $11-\mathrm{cm}^{3}$ cells compared to those grown in $19-$ and $40-\mathrm{cm}^{3}$ cells, but it did not vary with medium compression treatment.

The winter experiment determined the effect of cell size on plant growth. The RWR was high in plants grown in $2-\mathrm{cm}^{3}$ cells, but total plant growth was less than that of plants grown in the other flats. Small cell size increased the number of seedlings per unit area, consequently conserving medium, greenhouse space, fertilizer, and water. The crowding, however, caused more light competition, leading to less growth in the shoot compared to the roots. Medium compression caused a reduction in root growth and the root weight ratio. Whether higher root weight or the higher RWR increased plant quality and growth in the field was studied in subsequent field experiments.

Transplant growth (spring). Lettuce seedlings grown in the spring received higher light intensity compared to winter (691 vs. 521 $\mathrm{mol} \cdot \mathrm{m}^{-2}$, respectively, of total solar radiation), thus enhancing plant growth (22 DAS in spring vs. 24 DAS in winter). Plants from $2-\mathrm{cm}^{3}$ cells had fewer leaves; less total leaf area; lower shoot and total dry weights and RGR and NAR values; and increased SLA and RWR compared with plants grown in all other flats (Table 3). Trends were similar for plants grown in $11-\mathrm{cm}^{3}$ cells compared with plants grown in 19- and $40-\mathrm{cm}^{3}$ cells, except that NAR, SLA, and RWR values did not differ. Plants from $19-\mathrm{cm}^{3}$ cells seldom differed from plants grown in $40-\mathrm{cm}^{3}$ cells, confirming the trends of the winter experiment. The increased light intensity during spring likely led to increased leaf area in all plants with respect to winter.

Plants grown in 2- $\mathrm{cm}^{3}$ cells appeared to be too small to survive transplanting. To obtain larger plant size, additional plants were grown another week before planting in the field. Compared to the plants not given an extra week, these plants had higher shoot and total dry weights but lower RGR, NAR, LAR, and SLA values. Because the older transplants received the same amount of fertilizer as the 22-day-old plants, they may have had more fertilizer stress than the younger transplants (Leskovar et al., 1991). The lower waterholding capacity present in a small medium volume could have caused additional stress. Similar RWR values between the two treatments might be attributed to nutrient deficiency and dehydration, which could have decreased the permeability of roots, possibly due to suberization of the cell walls (Passioura, 1988).

Medium compression produced the same results as in the winter experiment. A cell size $\times$ medium compression interaction led to plants with short leaves and lower root dry weights when grown in $2-\mathrm{cm}^{3}$ cells and noncompressed medium compared to the corresponding plants grown in $11-, 19-$, and $40-\mathrm{cm}^{3}$ cells. Noncompressed medium led to shorter leaves and lower root dry weight in plants grown in 11$\mathrm{cm}^{3}$ cells compared to the corresponding plants grown in 19- and 40- $\mathrm{cm}^{3}$ cells. Plants grown in the same flats $\left(11-\mathrm{cm}^{3}\right.$ cells $)$ had shorter leaves and higher root dry weight when grown in noncompressed medium. Plants 29 days old had the same leaf length as 22-day-old plants when grown in flats with the same cell size (2 $\mathrm{cm}^{3}$ ) with noncompressed medium. Conversely, the older plants had higher root dry weights than the 22-day-old plants.

Table 3. Shoot and root growth characteristics of lettuce seedlings as affected by cell size and medium compression (noncompressed $=\mathrm{NC}$ and compressed $=\mathrm{C}$ ) 22 days after seeding (DAS) (spring).

\begin{tabular}{|c|c|c|c|c|c|c|c|c|c|c|c|c|c|}
\hline \multirow{3}{*}{$\begin{array}{l}\text { Growing } \\
\text { conditions }\end{array}$} & \multicolumn{4}{|c|}{ Leaf } & \multicolumn{4}{|c|}{ Dry wt (mg) } & \multirow{3}{*}{$\begin{array}{c}\mathrm{RGR}^{\mathrm{z}} \\
\left(\mathrm{mg} \cdot \mathrm{mg}^{-1} \cdot \mathrm{d}^{-1}\right)\end{array}$} & \multirow{3}{*}{$\begin{array}{c}\mathrm{NAR}^{\mathrm{z}} \\
\left(\mathrm{mg} \cdot \mathrm{cm}^{-2} \cdot \mathrm{d}^{-1}\right)\end{array}$} & \multirow{3}{*}{$\begin{array}{c}\mathrm{LAR}^{\mathrm{z}} \\
\left(\mathrm{cm}^{2} \cdot \mathrm{mg}^{-1}\right)\end{array}$} & \multirow{3}{*}{$\begin{array}{l}\operatorname{SLA}^{\mathrm{z}} \\
\left.\mathrm{m}^{2} \cdot \mathrm{mg}^{-1}\right)\end{array}$} & \multirow{3}{*}{$\mathrm{RWR}^{\mathrm{z}}$} \\
\hline & \multirow[b]{2}{*}{ Count } & \multicolumn{2}{|c|}{ Length $(\mathrm{mm})$} & \multirow{2}{*}{$\begin{array}{l}\text { Area } \\
\left(\mathrm{mm}^{2}\right)\end{array}$} & \multirow[b]{2}{*}{ Shoot } & \multicolumn{2}{|c|}{ Root } & \multirow[b]{2}{*}{ Total } & & & & & \\
\hline & & $\mathrm{NC}$ & $\overline{\mathrm{C}}$ & & & $\overline{\mathrm{NC}}$ & $\mathrm{C}$ & & & & & & \\
\hline \multicolumn{14}{|l|}{ Flat designation $\left(\mathrm{cm}^{3}\right)$} \\
\hline 2 & 3.3 & 83 & 107 & 1609 & 28 & 5 & 5 & 33 & 0.211 & 0.805 & 0.255 & 0.304 & 0.169 \\
\hline 11 & 4.3 & 123 & 136 & 4261 & 85 & 11 & 7 & 94 & 0.274 & 1.024 & 0.236 & 0.261 & 0.137 \\
\hline 19 & 4.9 & 138 & 146 & 6164 & 121 & 14 & 9 & 132 & 0.294 & 1.035 & 0.244 & 0.267 & 0.133 \\
\hline 40 & 5.1 & 141 & 146 & 7440 & 135 & 13 & 12 & 147 & 0.299 & 0.971 & 0.264 & 0.289 & 0.133 \\
\hline 2 (29 DAS) & 3.5 & 80 & 106 & 1835 & 44 & 8 & 8 & 51 & 0.168 & 0.728 & 0.188 & 0.221 & 0.166 \\
\hline Significance & $<0.001$ & \multicolumn{2}{|c|}{$<0.001^{\mathrm{y}}$} & $<0.001$ & $<0.001$ & \multicolumn{2}{|c|}{$<0.001^{\mathrm{y}}$} & $<0.001$ & $<0.001$ & $<0.001$ & $<0.001$ & $<0.001$ & $<0.001$ \\
\hline \multicolumn{14}{|c|}{ Orthogonal contrasts } \\
\hline $\begin{array}{l}2 \mathrm{~cm}^{3} \text { vs. others } \\
11 \text { vs. } 19 \text { and }\end{array}$ & $<0.001$ & \multicolumn{2}{|l|}{$1<0.001$} & $<0.001$ & $<0.001$ & \multicolumn{2}{|l|}{$<0.001$} & $<0.001$ & $<0.001$ & $<0.001$ & 0.339 & $<0.001$ & $<0.001$ \\
\hline $40 \mathrm{~cm}^{3}$ & $<0.001$ & \multicolumn{2}{|l|}{$<0.001$} & $<0.001$ & $<0.001$ & \multirow{2}{*}{\multicolumn{2}{|c|}{0.006}} & $<0.001$ & $<0.001$ & 0.490 & 0.033 & 0.055 & 0.150 \\
\hline 19 vs. $40 \mathrm{~cm}^{3}$ & 0.066 & & & 0.002 & 0.075 & & & 0.075 & 0.198 & 0.074 & 0.034 & 0.034 & 0.895 \\
\hline 2 (22 DAS) vs. & \multirow{3}{*}{0.066} & \multirow{3}{*}{\multicolumn{2}{|c|}{$\begin{array}{l}0.435 \\
0.005\end{array}$}} & & & \multirow{3}{*}{\multicolumn{2}{|c|}{$\begin{array}{l}0.002 \\
0.013\end{array}$}} & & & & & & \\
\hline $2 \mathrm{~cm}^{3}$ (29 DAS) & & & & 0.546 & 0.044 & & & 0.028 & $<0.001$ & 0.035 & $<0.001$ & $<0.001$ & 0.367 \\
\hline $\mathrm{NC}$ vs.C $\left(11 \mathrm{~cm}^{3}\right)$ & & & & & & & & & & & & & \\
\hline \multicolumn{14}{|l|}{ Media compression } \\
\hline $\mathrm{NC}$ & 4.0 & & 3829 & 77 & \multicolumn{2}{|l|}{10} & 87 & 0.246 & 0.951 & 0.225 & 0.259 & 0.156 \\
\hline $\mathrm{C}$ & 4.4 & \multicolumn{2}{|l|}{128} & 4695 & 87 & \multirow{2}{*}{\multicolumn{2}{|c|}{$<0.001$}} & 96 & 0.252 & 0.874 & 0.250 & 0.278 & 0.139 \\
\hline Significance & $<0.001$ & \multirow{2}{*}{\multicolumn{2}{|c|}{$\begin{array}{c}<0.001 \\
0.005\end{array}$}} & 0.001 & 0.038 & & & 0.101 & 0.014 & 0.002 & $<0.001$ & 0.006 & $<0.001$ \\
\hline Interaction & 0.084 & & & 0.653 & 0.884 & 0.017 & & 0.844 & 0.564 & 0.074 & 0.130 & 0.093 & 0.650 \\
\hline
\end{tabular}

${ }^{2} \mathrm{RGR}=$ relative growth rate, $\mathrm{NAR}=$ net assimilation rate, $\mathrm{LAR}=$ leaf area ratio, $\mathrm{SLA}=$ specific leaf area, and $\mathrm{RWR}=$ root weight ratio.

${ }^{y} P$ value for the main effect.

${ }^{\mathrm{x}}$ Others $=11+19+40 \mathrm{~cm}^{3}$ pooled treatments. 
Results from the spring experiment generally confirmed the trends of the winter. Growth was reduced when plants were grown in small cells, and biomass partitioning was affected greatly by cell volume. Plants grown in the smallest cell size did not increase in size when kept 1 week longer in the greenhouse. The small volume of medium in the $2-\mathrm{cm}^{3}$ cells became a limiting factor for sustained growth with plant age. Compression of the medium enhanced whole-plant growth but, again, caused a reduction in root growth and RWR.

Transplant growth (fall). Response of lettuce transplants to the smallest cell size $\left(2 \mathrm{~cm}^{3}\right)$ was similar to that in winter and spring experiments (Tables 2 and 3); plant growth was always less than that for plants from the other flats, with the lowest RGR and NAR values (Table 4). Plants were not etiolated, which indicated there was no overcrowding of the plants. Plants grew less due to small medium volume and amount and consequent presumed water and fertilizer stress. As in the winter experiment, the LAR was least for plants grown in $2-\mathrm{cm}^{3}$ cells. Because SLA was not significantly affected, the low LAR values were attributed to the LAR second component, the allocation of biomass to the leaves (LWR). The dramatic increase of RWR (decrease in LWR) in plants grown in the $2-\mathrm{cm}^{3}$ cells caused LAR values to decrease. Transplants grown in $11-\mathrm{cm}^{3}$ cells had fewer leaves; less leaf area; lower shoot, root, and total dry weights; and reduced RGR, NAR, and LAR than plants grown in 19- or $40-\mathrm{cm}^{3}$ cells. However, as in the winter and spring experiments, the RWR did not change. Opposite to those of the other two studies, growing plants in $40-\mathrm{cm}^{3}$ cells enhanced growth compared to growing them in $19-\mathrm{cm}^{3}$ cells. However, the RWR was higher in $19-\mathrm{cm}^{3}$ cells.

The effect of the largest cell size on RWR was not consistent over the three experiments. In the winter experiment, RWR values were higher for plants grown in $40-\mathrm{cm}^{3}$ cells than for those grown in $19-\mathrm{cm}^{3}$ cells. In the spring experiment, RWR did not differ between these two treatments, and in fall, RWR was higher for the plants grown in $19-\mathrm{cm}^{3}$ cells. The SLA trends in the first two experiments could explain the RWR values (Tables 2 and 3), but in this third experiment, SLA values did not differ. The RWR may have been affected by an unrecognized variable that was not kept constant in this experiment. For example, plants were fertilized once in the third experiment, twice in the other two. Lower nutrient levels possibly detrimentally affected the RWR in the biggest cells $\left(40 \mathrm{~cm}^{3}\right)$.

Medium compression affected plant morphology in a manner similar to that in the first two experiments.

Field study (spring). Plants grown in sandy soil (North Florida) were sampled in the field at 12 (Table 5) and 26 DAT and at crop maturity. Growth rates $\leq 12$ DAT (data not shown) were lower than those before transplanting, possibly due to transplant acclimation or transplant shock. However, trends were consistent with those at transplanting. The 2$\mathrm{cm}^{3}$ cells and noncompressed medium resulted in plants with less leaf area and lower shoot, root, and total dry weights than plants from the other flats with noncompressed medium (interaction effect). Also consistent with the transplanting data, plants from $11-\mathrm{cm}^{3}$ cells and noncompressed medium had less leaf area and lower shoot, root, and total dry weights than those from 19 - and $40-\mathrm{cm}^{3}$ cells. The compression of the medium in $11-\mathrm{cm}^{3}$ cells did not affect plant leaf area or dry weights $(P>0.05)$. Keeping the plants in the greenhouse 1 week longer did not result in any beneficial effect on growth compared to the corresponding treatment transplanted 22 DAS.

Data from the sample 26 DAT are not shown because few treatment effects were significant.

At harvest (Table 6), head weight and width were not affected by treatment; however, head height, stem length, and the height : width ratio were affected. In particular, lettuce heads from plants grown in $19-\mathrm{cm}^{3}$ cells during the seedling stage were taller than those from $40-\mathrm{cm}^{3}$ cells. Lettuce heads from plants grown in $2-\mathrm{cm}^{3}$ cells for 22 days were taller than those grown for 29 days. Lettuce stems were longer only in the case of plants grown in $2-\mathrm{cm}^{3}$ cells for 22 days compared to plants grown in the other flats. Medium compression did not affect production. Interaction between treatments was significant for the height : width ratio, but none of the preplanned contrasts showed significant differences.

This experiment indicated that cell size and medium compression did not affect lettuce head production, although the transplants were affected significantly by these treatments in the greenhouse. However, the largest cell sizes (19- and $40-\mathrm{cm}^{3}$ cells) enhanced earliness of harvest, while the smallest cell size delayed harvest by 13 days compared to plants in the largest cells. Using $11-\mathrm{cm}^{3}$ cells did not affect harvest date. Furthermore, the smallest cells $\left(2 \mathrm{~cm}^{3}\right)$ caused heads with longer stems than the other cell sizes.

Field study (fall). Cell size and medium compression during transplant growth did not affect yield in Belle Glade (data not shown). At maturity, plants from $2-\mathrm{cm}^{3}$ cells grown in Gainesville (Table 7) had shorter stems and lighter, shorter, and narrower heads than all other plants. Heads were taller when grown in $40-\mathrm{cm}^{3}$ cells compared to $19-\mathrm{cm}^{3}$ cells. Heads were wider when grown in $19-$ and $40-\mathrm{cm}^{3}$ cells than in $11-\mathrm{cm}^{3}$ cells.

Short stems are an important head quality aspect. In this study, stems were generally shorter at the end of the fall experiment, possibly due to the season. Shorter stems were particularly evident in plants grown in $2-\mathrm{cm}^{3}$ cells; stems of these heads were $31 \mathrm{~mm}$ long in the fall experiment but $61 \mathrm{~mm}$ in spring. Opposite to the spring experiment, heads of plants grown in $2-\mathrm{cm}^{3}$ cells in fall were smaller than the others in terms of weight, height, and width. Heads of plants from $11-\mathrm{cm}^{3}$ cells had a smaller diameter than those from 19- and 40$\mathrm{cm}^{3}$ cells. Heads were taller when the transplants were grown in $40-\mathrm{cm}^{3}$ cells than in 19$\mathrm{cm}^{3}$ cells. Medium compression led to decreased head height at maturity. All the other variables were equal, regardless of medium density.

Table 4. Shoot and root growth characteristics of lettuce seedlings as affected by cell size and medium compression (noncompressed $=$ NC and compressed $=\mathrm{C}$ ) 26 days after seeding (fall).

\begin{tabular}{|c|c|c|c|c|c|c|c|c|c|c|c|}
\hline \multirow{3}{*}{$\begin{array}{l}\text { Growing } \\
\text { conditions }\end{array}$} & \multicolumn{3}{|c|}{ Leaf } & \multirow{2}{*}{\multicolumn{3}{|c|}{ Dry wt (mg) }} & \multirow{3}{*}{$\begin{array}{c}\mathrm{RGR}^{\mathrm{z}} \\
\left(\mathrm{mg} \cdot \mathrm{mg}^{-1} \cdot \mathrm{d}^{-1}\right)\end{array}$} & \multirow{3}{*}{$\begin{array}{c}\mathrm{NAR}^{\mathrm{z}} \\
\left(\mathrm{mg} \cdot \mathrm{cm}^{-2} \cdot \mathrm{d}^{-1}\right)\end{array}$} & \multirow{3}{*}{$\begin{array}{c}\mathrm{LAR}^{\mathrm{z}} \\
\left(\mathrm{cm}^{2} \cdot \mathrm{mg}^{-1}\right)\end{array}$} & \multirow{3}{*}{$\begin{array}{c}\mathrm{SLA}^{\mathrm{z}} \\
\left(\mathrm{cm}^{2} \cdot \mathrm{mg}^{-1}\right)\end{array}$} & \multirow{3}{*}{$\begin{array}{c}\mathrm{RWR}^{\mathrm{z}} \\
\left(\mathrm{mg} \cdot \mathrm{mg}^{-1}\right)\end{array}$} \\
\hline & \multirow[b]{2}{*}{ Count } & \multirow{2}{*}{$\begin{array}{l}\text { Length } \\
(\mathrm{mm})\end{array}$} & \multirow{2}{*}{$\begin{array}{l}\text { Area } \\
\left(\mathrm{mm}^{2}\right)\end{array}$} & & & & & & & & \\
\hline & & & & Shoot & Root & Total & & & & & \\
\hline \multicolumn{12}{|l|}{ Flat designation $\left(\mathrm{cm}^{3}\right)$} \\
\hline 2 & 3.2 & 76 & 1286 & 27 & 6 & 33 & 0.197 & 0.946 & 0.199 & 0.245 & 0.186 \\
\hline 11 & 4.4 & 136 & 7079 & 132 & 16 & 148 & 0.282 & 0.989 & 0.251 & 0.283 & 0.146 \\
\hline 19 & 4.9 & 130 & 8179 & 178 & 24 & 202 & 0.299 & 1.184 & 0.210 & 0.241 & 0.153 \\
\hline 40 & 5.8 & 151 & 13,467 & 280 & 30 & 310 & 0.324 & 1.146 & 0.228 & 0.254 & 0.139 \\
\hline Significance & $<0.001$ & 0.006 & $<0.001$ & $<0.001$ & $<0.001$ & $<0.001$ & $<0.001$ & 0.009 & 0.010 & 0.088 & $<0.001$ \\
\hline \multicolumn{12}{|l|}{ Orthogonal contrasts } \\
\hline $2 \mathrm{~cm}^{3}$ vs. others ${ }^{y}$ & $<0.001$ & $<0.001$ & $<0.001$ & $<0.001$ & $<0.001$ & $<0.001$ & $<0.001$ & 0.014 & 0.017 & & $<0.001$ \\
\hline $40 \mathrm{~cm}^{3}$ & $<0.001$ & 0.414 & 0.001 & $<0.001$ & $<0.001$ & $<0.001$ & $<0.001$ & 0.012 & 0.020 & & 0.998 \\
\hline 19 vs. $40 \mathrm{~cm}^{3}$ & 0.003 & 0.006 & $<0.001$ & 0.001 & 0.029 & 0.001 & 0.003 & 0.614 & 0.227 & & 0.017 \\
\hline \multicolumn{12}{|l|}{ Media compression } \\
\hline $\mathrm{NC}$ & 4.4 & 116 & 6560 & 138 & 19 & 157 & 0.267 & 1.065 & 0.214 & 0.252 & 0.164 \\
\hline $\mathrm{C}$ & 4.8 & 131 & 8446 & 170 & 19 & 190 & 0.284 & 1.068 & 0.229 & 0.260 & 0.148 \\
\hline Significance & 0.046 & $<0.001$ & 0.029 & 0.106 & 0.937 & 0.132 & 0.003 & 0.957 & 0.171 & 0.515 & 0.001 \\
\hline Interaction & 0.825 & 0.517 & 0.580 & 0.804 & 0.881 & 0.845 & 0.102 & 0.834 & 0.854 & 0.962 & 0.143 \\
\hline
\end{tabular}

${ }^{2} \mathrm{RGR}=$ relative growth rate, $\mathrm{NAR}=$ net assimilation rate, $\mathrm{LAR}=$ leaf area ratio, SLA $=$ specific leaf area, and $\mathrm{RWR}=$ root weight ratio.

${ }^{\mathrm{y}}$ Others $=11+19+40 \mathrm{~cm}^{3}$ pooled treatments. 
Table 5. Shoot and root growth characteristics of lettuce seedlings as affected by cell size and medium compression (noncompressed $=\mathrm{NC}$ and compressed $=\mathrm{C}$ ) 12 days after transplanting in the field in Gainesville, Fla., in sandy soil (spring).

\begin{tabular}{|c|c|c|c|c|c|c|c|c|}
\hline \multirow{3}{*}{$\begin{array}{l}\text { Growing } \\
\text { conditions }\end{array}$} & & & \multicolumn{6}{|c|}{ Dry wt (mg) } \\
\hline & \multicolumn{2}{|c|}{ Leaf area $\left(\mathrm{mm}^{2}\right)$} & \multicolumn{2}{|c|}{ Shoot } & \multicolumn{2}{|c|}{ Root } & \multicolumn{2}{|c|}{ Total } \\
\hline & $\mathrm{NC}$ & $\mathrm{C}$ & $\overline{\mathrm{NC}}$ & $\overline{\mathrm{C}}$ & $\overline{\mathrm{NC}}$ & $\overline{\mathrm{C}}$ & $\overline{\mathrm{NC}}$ & $\mathrm{C}$ \\
\hline \multicolumn{9}{|l|}{$\begin{array}{l}\text { Flat designation }\left(\mathrm{cm}^{3}\right) \text { [days } \\
\text { after seeding (DAS)] }\end{array}$} \\
\hline $2(22)$ & 1061 & 1181 & 33 & 37 & 12 & 12 & 44 & 49 \\
\hline $11(22)$ & 2897 & 3345 & 101 & 135 & 35 & 35 & 136 & 170 \\
\hline $19(22)$ & 4614 & 4676 & 173 & 194 & 45 & 49 & 218 & 243 \\
\hline $40(22)$ & 5249 & 8562 & 216 & 360 & 53 & 84 & 269 & 444 \\
\hline $2(29)$ & 891 & 984 & 33 & 36 & 10 & 10 & 44 & 47 \\
\hline \multicolumn{9}{|l|}{ Significance } \\
\hline Interaction & \multicolumn{2}{|c|}{0.005} & \multicolumn{2}{|c|}{0.006} & \multicolumn{2}{|c|}{0.039} & \multicolumn{2}{|c|}{0.007} \\
\hline \multicolumn{9}{|l|}{ Orthogonal contrasts } \\
\hline 2 (22 DAS) vs. others ${ }^{2}$ & \multicolumn{2}{|c|}{$<0.001$} & \multicolumn{2}{|c|}{$<0.001$} & \multicolumn{2}{|c|}{$<0.001$} & \multicolumn{2}{|c|}{$<0.001$} \\
\hline 11 vs. 19 and $40 \mathrm{~cm}^{3}$ & \multicolumn{2}{|c|}{0.001} & \multicolumn{2}{|c|}{$<0.001$} & \multicolumn{2}{|c|}{0.045} & \multicolumn{2}{|c|}{0.001} \\
\hline $2(22$ DAS $)$ vs. $2(29$ DAS $)$ & \multicolumn{2}{|c|}{0.797} & \multicolumn{2}{|c|}{0.978} & \multicolumn{2}{|c|}{0.878} & \multicolumn{2}{|c|}{0.990} \\
\hline NC vs.C $\left(11 \mathrm{~cm}^{3}\right)$ & \multicolumn{2}{|c|}{0.499} & \multicolumn{2}{|c|}{0.230} & \multicolumn{2}{|c|}{0.983} & \multicolumn{2}{|c|}{0.337} \\
\hline
\end{tabular}

Table 6. Head characteristics and yield of lettuce at maturity as affected by cell size and medium compression (noncompressed $=\mathrm{NC}$ and compressed $=\mathrm{C}$ ) from plants grown in Gainesville, Fla., in sandy soil (spring).

\begin{tabular}{|c|c|c|c|c|c|c|}
\hline \multirow{3}{*}{$\begin{array}{l}\text { Growing } \\
\text { conditions }\end{array}$} & \multicolumn{3}{|c|}{ Head size } & \multirow{3}{*}{$\begin{array}{l}\text { Stem } \\
\text { length } \\
(\mathrm{mm})\end{array}$} & \multirow{2}{*}{\multicolumn{2}{|c|}{ Ht : Width }} \\
\hline & \multirow{2}{*}{$\begin{array}{l}\text { Wt } \\
(\mathrm{g})\end{array}$} & \multirow{2}{*}{$\begin{array}{c}\mathrm{Ht} \\
(\mathrm{mm})\end{array}$} & \multirow{2}{*}{$\begin{array}{l}\text { Width } \\
(\mathrm{mm})\end{array}$} & & & \\
\hline & & & & & $\mathrm{NC}$ & $\mathrm{C}$ \\
\hline \multicolumn{7}{|l|}{$\begin{array}{l}\text { Flat designation }\left(\mathrm{cm}^{3}\right) \text { [days } \\
\text { after seeding (DAS)] }\end{array}$} \\
\hline $2(22)$ & 646 & 148 & 119 & 61 & 1.212 & 1.278 \\
\hline $11(22)$ & 571 & 144 & 114 & 45 & 1.247 & 1.295 \\
\hline $19(22)$ & 545 & 151 & 114 & 32 & 1.324 & 1.322 \\
\hline $40(22)$ & 578 & 141 & 115 & 37 & 1.323 & 1.137 \\
\hline $2(29)$ & 576 & 136 & 118 & 57 & 1.140 & 1.172 \\
\hline Significance & 0.164 & 0.030 & 0.535 & $<0.001$ & & \\
\hline \multicolumn{7}{|l|}{ Orthogonal contrasts } \\
\hline 2 (22 DAS) vs. others ${ }^{y}$ & & 0.482 & & $<0.001$ & 0.093 & \\
\hline 11 vs. 19 and $40 \mathrm{~cm}^{3}$ & & 0.732 & & 0.058 & 0.160 & \\
\hline 19 vs. $40 \mathrm{~cm}^{3}$ & & 0.049 & & 0.457 & & \\
\hline \multicolumn{7}{|l|}{2 (22 DAS) vs. } \\
\hline $2(29$ DAS $) \mathrm{cm}^{3}$ & & 0.014 & & 0.508 & 0.251 & \\
\hline $\mathrm{NC}$ vs. $\mathrm{C}\left(11 \mathrm{~cm}^{3}\right)$ & & & & & 0.439 & \\
\hline \multicolumn{7}{|l|}{ Media compression } \\
\hline $\mathrm{NC}$ & 584 & 143 & 115 & 49 & 1.249 & \\
\hline $\mathrm{C}$ & 582 & 145 & 117 & 43 & 1.241 & \\
\hline Significance & 0.937 & 0.688 & 0.462 & 0.124 & 0.755 & \\
\hline Interaction & 0.333 & 0.437 & 0.305 & 0.555 & & \\
\hline
\end{tabular}

${ }^{\mathrm{z} P}$ value for the main effect.

${ }^{\mathrm{y}}$ Others $=11+19+40 \mathrm{~cm}^{3}$ pooled treatments.

Table 7. Head characteristics and yield of lettuce at maturity as affected by cell size and medium compression (noncompressed $=$ NC and compressed $=\mathrm{C}$ ) from plants grown in Gainesville, Fla., in sandy soil (fall).

\begin{tabular}{|c|c|c|c|c|c|}
\hline \multirow[b]{2}{*}{$\begin{array}{l}\text { Growing } \\
\text { conditions }\end{array}$} & \multicolumn{3}{|c|}{ Head size } & \multirow{2}{*}{$\begin{array}{c}\text { Stem } \\
\text { length } \\
(\mathrm{mm})\end{array}$} & \multirow[b]{2}{*}{ Ht : width } \\
\hline & $\begin{array}{l}\text { Wt } \\
(\mathrm{g}) \\
\end{array}$ & $\begin{array}{c}\mathrm{Ht} \\
(\mathrm{mm})\end{array}$ & $\begin{array}{l}\text { Width } \\
(\mathrm{mm})\end{array}$ & & \\
\hline \multicolumn{6}{|l|}{ Flat designation $\left(\mathrm{cm}^{3}\right)$} \\
\hline 2 & 704 & 116 & 115 & 31 & 1.00 \\
\hline 11 & 775 & 122 & 122 & 32 & 1.00 \\
\hline 19 & 767 & 123 & 127 & 33 & 0.97 \\
\hline 40 & 769 & 126 & 129 & 35 & 0.98 \\
\hline Significance & 0.028 & $<0.001$ & $<0.001$ & 0.001 & 0.149 \\
\hline \multicolumn{6}{|l|}{ Orthogonal contrasts } \\
\hline $2 \mathrm{~cm}^{3}$ vs. others ${ }^{\mathrm{z}}$ & 0.003 & $<0.001$ & $<0.001$ & 0.002 & \\
\hline 11 vs. 19 and $40 \mathrm{~cm}^{3}$ & 0.727 & 0.084 & 0.013 & 0.051 & \\
\hline 19 vs. $40 \mathrm{~cm}^{3}$ & 0.925 & 0.019 & 0.359 & 0.026 & \\
\hline \multicolumn{6}{|l|}{ Media compression } \\
\hline $\mathrm{NC}$ & 751 & 123 & 124 & 33 & 0.99 \\
\hline $\mathrm{C}$ & 757 & 121 & 122 & 33 & 0.99 \\
\hline Significance & 0.745 & 0.039 & 0.226 & 0.770 & 0.763 \\
\hline Interaction & 0.978 & 0.116 & 0.324 & 0.804 & 0.085 \\
\hline
\end{tabular}

${ }^{\mathrm{z}}$ Others $=11+19+40 \mathrm{~cm}^{3}$ pooled treatments.
As noted in tomato and pepper (Basoccu and Nicola, 1989, 1990; Weston and Zandra, 1986), increased cell volume during the seedling production stage resulted in increased plant growth at transplanting. In our experiments, RWR decreased as the cell volume increased. Consequently, plants at transplanting manifested different root and shoot biomass distribution. However, yield response in the field was more affected by soil characteristics and climatic conditions than in a controlled environment, such as the greenhouse. In fact, in muck soil and the warm conditions of fall, increased cell size in the greenhouse did not enhance head weight at maturity. The daily mean temperature was always higher in Belle Glade than in Gainesville(20.3 vs. 13.5C, respectively). In addition, harvest was delayed 19 days for plants grown in the largest cell sizes (40- and $19-\mathrm{cm}^{3}$ cells), probably due to poor root development, which is detrimental under warm growing conditions. The small root weight ratio could lead to transpiration loss by the leaves.

In sandy soil, there were differences during the fall study in maturation time and head weight: small cell size $\left(2 \mathrm{~cm}^{3}\right)$ delayed harvest and also reduced head weight at maturity. In spring, only maturation was delayed in plants from $2-\mathrm{cm}^{3}$ cells. In all our studies, no difference in head weight was found among plants grown in 11-, 19-, and 40- $\mathrm{cm}^{3}$ cells, implying that using the smaller cells $\left(11 \mathrm{~cm}^{3}\right)$ among these three types was not detrimental to yield compared to using larger cells. In addition, compressing the medium in the cells was not justified from our results because it is more costly and did not benefit yield in the field.

\section{Literature Cited}

Aguila-Sancho, J.F. 1988. The present status of the substrate as an ecosystem component and its function and importance in crop productivity. Acta Hort. 221:53-74.

Baligar, V.C., V.E. Nash, M.L. Hare, and J.A. Price. 1975. Soybean root anatomy as influenced by soil bulk density. Agron. J. 67:842-844.

Basoccu, L. and S. Nicola. 1989. Effetti delle condizioni di luce naturale, dello stato idrico e del volume del substrato sull'accrescimento in vivaio e sulla produttività del pomodoro in serra fredda, p. 359-376. In: P. Guarella (ed.). Proc. $1^{\circ}$ Convegno Nazionale in Il vivaismo orticolo, aspetti tecnici organizzativi e commerciali. Foggia, Italy, 4-5 May 1989.

Basoccu, L. and S. Nicola. 1990. Influence of different growing techniques on seedlings and fruit production of pepper (Capsicum annuиm L.), p. 4056. In: Proc. 23rd Intl. Hort. Congr., Intl. Soc. Hort. Sci. Florence, Italy, 27 Aug.-1 Sept. 1990. (Abstr.)

Beirenger, L. and R. Bostdorff. 1989. Innovative transplanting production systems from Speedling. ASHS 1989 Annu. Mtg., Tulsa, Okla., Prog. \& Abstr. p. 146.

Bennie, A.T. 1991. Growth and mechanical impedance, p. 393-416. In: Y. Waisel, A. Eshel, and U. Kafkafi (eds.). Plants roots: The hidden half. Marcel Dekker, New York.

Chipman, E.W. 1961. The effect of seeding and plant topping on the production of early and total yields of ripe tomatoes. Proc. Amer. Soc. Hort. Sci. 77:483-487.

Drew, M.C. and L.H. Stolzy. 1991. Growth under 
oxygen stress, p. 331-350. In: Y. Waisel, A. Eshel, and U. Kafkafi (eds.). Plant roots: The hidden half. Marcel Dekker, New York.

Gianquinto, G. 1991. Ricerche sulla modalità di allevamento in vivaio di piantine di lattuga cappuccia (Lactuca sativa L. var. capitata (L.) Janchen): Riflessi sulla produzione in coltura protetta. Colture Protette 1:83-89.

Hall, M.R. 1989. Cell size of seedling containers influences early vine growth and yield of transplanted watermelon. HortScience 24:771-773.

Hunt, R. 1978. Plant growth analysis. Edward Arnold, London.

Hunt, R. 1982. Plant growth curves. The functional approach to plant growth analysis. Edward Arnold, London.

Knavel, D.E. 1965. Influence of container, container size, and spacing on growth of transplants and yield in tomato. Proc. Amer. Soc. Hort. Sci. 86:582-586.

Kretchman, D.W. and T.H. Short. 1977. A further evaluation of transplants for processing tomatoes in Ohio. Ohio Agr. Res. and Development Ctr., Wooster, Hort. Ser. 443.

Leskovar, D.J., D.J. Cantliffe, and P.J. Stoffella. 1991. Growth and yield of tomato plants in response to age of transplants. J. Amer. Soc. Hort. Sci. 116:416-420.

Nicklow, C.W. and P.A. Minges. 1962. Plant growing factors influencing the field performance of the Fireball tomato variety. Proc. Amer. Soc. Hort. Sci. 81:443-450.

Passioura, J.B. 1988. Water transport in and to roots. Annu. Rev. Plant Physiol. Plant Mol. Biol. 39:245-265.

Prihar, S.S., M.R. Choudhary, and T.M. Varghese.
1971. Effect of post-planting loosening of unstable soil on the anatomy of corn root. Plant Soil 35:57-63.

Steenkamp, P.A. 1987. Die invloed van grondverdigting op die morfologie en sekere fisiologiese aktiwiteite van grondboon, katoenen mieliewortels (The influence of soil compaction on the morphology and physiological activity of groundnut, cotton and maize roots). MS Thesis, Univ. of the Orange Free State, Bloemfontein, South Africa.

Vavrina, C.S., S. Olson, and J.A. Cornell. 1993. Watermelon transplant age: Influence on fruit yield. HortScience 28:789-790.

Weston, L.A. and B. Zandra. 1986. Effect of root container size and location of production on growth and yield of tomato transplants. J. Amer. Soc. Hort. Sci. 111:498-501. 